\title{
Dampak Good Government Governance terhadap Kinerja Value For Money Method pada Satuan Kerja -Perangkat Daerah
}

\author{
Bambang Jatmiko ${ }^{1}$ \\ Universitas Muhammadiyah \\ Yogyakarta, Indonesia \\ Email: bambang_jatmiko65@yahoo.com
}

\author{
Eliza Damayanti2 \\ Universitas Muhammadiyah \\ Yogyakarta, Indonesia
}

\begin{abstract}
ABSTRAK
Penelitianini bertujuan untuk menguji dan membuktikan secara empiris dampak Good Government Governance yang terdiri dari Transparansi, Akuntabilitas, dan Aturan Hukum terhadap Kinerja Value for Money pada Unit Kerja Daerah (SKPD) di Kabupaten Kebumen. Metode penelitian dalam penelitian ini menggunakan teknik purposive sampling yaitu teknik penentuan sampel dengan pertimbangan tertentu. Populasi dalam penelitian ini a dalah Sekretaris, KepalaSubbagian, Kepala Bagian, dan Kepala Bagian diSKPD Kabupaten Kebumen. Dalam penelitian ini sampel sebanyak 91 responden. Alat analisis yang digunakan dalam penelitian ini adalah regresi linier bergdana menggunakan SPSS versi 15 untuk Windows. Hasil pengujian menunjukkan bahwa sebagian transparansi dan aturan hukum memiliki pengaruh positif yang signifikan terhadap ekonomi, efisiensi, dan efektivitas, sedangkan akuntabilitas tidak memiliki pengaruh signifikan terhadap ekonomi, efisiensi, dan efektivitas.
\end{abstract}

Kata Kunci: Good Government Governance; Value for Money.

\section{The Impact Of Good Government Governance On Value For Money Method Performance On Working Units - Regional Devices}

\section{ABSTRACT}

This study aims to test dan empirically prove the impact of Good Government Governance which consists of Transparency, Accountability, dan Legal Rules on the Performance of Value for Money on Regional Work Units (SKPD) in Kebumen Regency. The research method in this study uses a purposive sampling technique that is the technique of determining the sample with certain considerations. The population in this study is the Secretary, Head of Subdivision, Head of Division, dan Head of Section at SKPD Kebumen Regency. In this study a sample of 91 respondents. The analytical tool used in this study is multiple linear regression using SPSS version 15 for Windows. The test results show that partially transparency dan legal rules have a significant positive effect on economics, efficiency, dan effectiveness, while accountability does not have a significant effect on economics, efficiency, dan effectiveness.

Keywords: Good Government Governance; Value for Money.

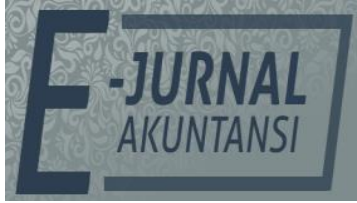

E-JA

e-Jurnal Akuntansi e-ISSN 2302-8556

Vol. 30 No. 5

Denpasar, Mei 2020

Hal.1114-1130

Artikel Masuk:

29 Maret 2020

Tanggal Diterima: 22 Mei 2020 


\section{PENDAHULUAN}

Otonomi daerah telah dilaksanakan sesuai dengan ketetapan MPR Nomor XV/MPR/1998 yaitu mengenai penyelenggaraan otonomi daerah ; pemanfaatan sumber daya nasional serta perimbangan keuangan pusat dan daerah. Desentralisasi fiskal pada Pemerintah Daerah diatur pada UU No. 32 Tahun 2004 telah mengembangkan sektor publik pada era baru dalam pelaksanaan otonomi daerah. Peran penting sektor publik yaitu memberikan pelayanan terhadap masyarakat guna mewujudkan masyarakat yang sejahtera dan dapat terpenuhinya semua kebutuhan yang diperlukan oleh masyarakat. Layanan ini biasanya akan membutuhkan pengeluaran dan biaya dalam jumlah yang tidak sedikit dan sumber daya lainnya yang ada dengan jumlah yang terbatas (Ramakrishnan 2013).

Pemerintah Daerah merupakan pihak yang diamanahkan tanggungjawab dalam menjalankan tugas pelayanan terhadap masyarakat. Pemerintah daerah dituntut untuk bertanggung jawab terhadap kinerja yang berorientasi pada kepentingan masyarakat dan untuk tanggap pada masyarakat dan memberikan pelayanan yang terbaik (Intihanah \& Muthia 2016). Keberhasilan suatu pelayanan atau program pemerintah daerah tersebut dapat dilihat dari capaian kinerja. Kinerja adalah suatu keberhasilan yang telah dicapai oleh anggota dalam merealisasikan sasaran organisasi yang telah ditentukan (Wuldanari \& Endah 2011). Pengukuran kinerja pemerintah dapat diukur dengan menggunakan indikator diantaranya Value for Money Method dan Laporan Akuntabilitas Keuangan Instansi Pemerintah (LAKIP) (Lestiawan \& Jatmiko 2015). Banyak sekali penelitian terdahulu yang membahas hubungan signifikan antara Good Government Governance dengan kinerja pemerintah daerah.

Gap masih terjadi di antara penelitian terdahulu. Penelitian terdahulu yang dilakukan oleh (Prayoga 2017) (Lestiawan \& Jatmiko 2015) menjelaskan bahwa Good Governance memiliki pengaruh signifikan terhadap kinerja Satuan Kerja Perangkat Daerah (SKPD).

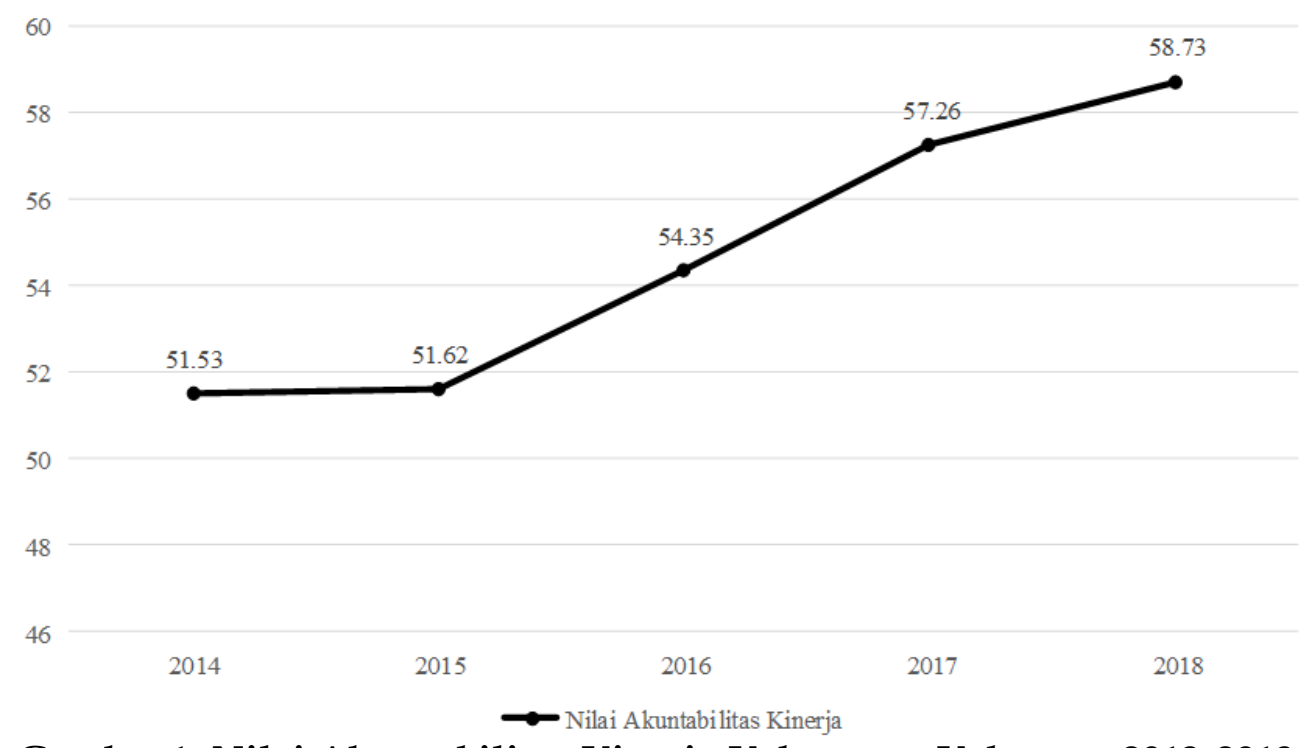

Gambar 1. Nilai Akuntabilitas Kinerja Kabupaten Kebumen 2013-2018 Sumber : Data Penelitian, 2018 
Gambar 1 menunjukkan nilai akuntabilitas kinerja Kabupaten Kebumen tahun 2013 hingga 2018. Target penilaian yang diharapkan yaitu B, namun Kabupaten Kebumen masih termasuk ke dalam kabupaten yang mendapaktan penilaian akuntabilitas dengan nilai CC. Nilai akuntabilitas kinerja Kabupaten Kebumen memang mengalami kenaikan selama lima tahun dari tahun 2014-2018, namun kenaikan tersebut masih belum memenuhi target yang telah ditetapkan. Hal tersebut menunjukkan bahwa akuntabilitas Kabupaten Kebumen masih terbilang cukup rendah. Penilaian tersebut juga menunjukkan bahwa prinsip Good Government Governance belum dapat dikatakan baik. Melalui web resmi Bappeda Kabupaten Kebumen (1) dijelaskan pula, bahwa salah satu kendala atau permasalahan yang terjadi pada pemerintah Kabupaten Kebumen adalah belum optimalnya implementasi Good Government Governance.

Agency Theory merupakan teori yang menjelaskan mengenai hubungan antara agen dengan prinsipal. Konsep agency theory dalam lingkup pemerintah daerah muncul ketika pemerintah daerah berusaha untuk memaksimalkan kepentingan pribadinya, seperti melakukan laporan keuangan yang tidak sesuai, sehingga posisi mereka terlihat aman dimata masyarakat. Implikasi teori agensi dalam penelitian ini yaitu dapat menjelaskan peran pemerintah daerah (agent) sebagai pihak yang diberikan tanggungjawab dan amanah oleh masyarakat (principal) harus bertindak sesuai dengan kepentingan masyarakat dengan melaksanakan tugas dan fungsinya sesuai dengan prinsip akuntabilitas, transparansi, dan aturan hukum, sehingga masalah-masalah keagenan yang sering muncul dalam lingkup pemerintah daerah dapat diminimalisir dan dapat mengurangi terjadinya penyelewengan-penyelewengan yang dilakukan oleh pemerintah daerah.

Istilah Governance pada dasarnya bukanlah termasuk ke dalam konsep yang baru, akan tetapi munculnya Governance semakin mengambil alih konsep dari manajemen, karena pada dasarnya antara Governance dan mananjemen sama-sama memiliki kesamaan, namun tetap ada perbedaan antara keduanya (Pratolo \& Jatmiko 2017). Transparansi merupakan suatu prinsip yang memberikan jaminan kepada masyarakat mengenai keterbukaan informasi dan kebebasan informasi sehingga dapat diakses oleh publik tentang kinerja pemerintah dari mulai penyelenggaran sampai pada tahap capaian (Pratolo \& Jatmiko 2017).

Akuntabilitas merupakan konsep etika yang berkaitan dengan pertanggungjawaban pada pemerintah. Aturan hukum merupakan suatu proses agar tercapaianya keinginan hukum menjadi hal yang nyata (Rahardjo 1983). Kinerja merupakan output/hasil dari suatu kegiatan yang telah atau baru akan tercapai sesuai dengan anggaran yang telah terukur. Kinerja merupakan bentuk dari capaian dan hasil dari suatu pelaksanaan visi misi organisasi yang telah dilakukan (Pratolo \& Jatmiko 2017).

Transparansi merupakan salah satu dari prinsip Good Government Governance. Transparansi berarti memberikan kebebasan kepada publik untuk dapat memperoleh informasi secara terbuka mengenai program dan kinerja yang telah dilaksanakan oleh pemerintah. Hal tersebut dapat mempengaruhi ekonomis kinerja pemerintah daerah yang merupakan salah satu dari prinsip Value for Money, karena segala bentuk pemborosan anggaran yang dilakukan 
oleh pejabat publik dapat diketahui melalui transparansi capaian anggaran tersebut. Hal tersebut didukung dengan penelitian yang dilakukan oleh (Pratolo, Jatmiko, \& Ardhi 2015) (Ljungholm 2015). Selain itu, penelitian yang dilakukan oleh (Setiyaningrum 2016) menjelaskan bahwa terhadap hubungan yang positif dan signifikan antara transparansi dengan kinerja anggaran berkonsep Value for Money. Penelitian lain yang dilakukan oleh (Fajarningtyas, Muslimin, \& Kahar 2016) (Intihanah \& Muthia 2016) yang mengungkapkan bahwa terdapat pengaruh yang positif dan signifikan antara Good Government Governance melalui prinsip trnsparansi terhadap kinerja Value for Money. Maka berdasarkan keterangan di atas dapat diturunkan hipotesis sebagai berikut :

$\mathrm{H}_{1}$ : Transparansi berpengaruh positif terhadap Ekonomis.

Akuntabilitas merupakan bentuk pertanggungjawaban yang dilakukan oleh pejabat publik atas capaian kinerja yang telah dilakukan selama satu periode. Penerapan akuntabilitas yang baik pada Pemerintah Daerah akan membuat pejabat publik memiliki rasa tanggungjawab yang lebih tinggi dalam mengelola anggaran yang diberikan oleh Pemerintah Pusat. Hal tersebut didukung oleh penelitian sebelumnya yang dilakukan oleh (Ferry, Eckrersley, \& Zakaria 2015) bahwa akuntabilitas memiliki implikasi siginifikan terhadap layanan publik. Selain itu (Fajarningtyas, Muslimin, \& Kahar 2016) menjelaskan bahwa terdapat pengaruh yang signifikan dan positif antara akuntabilitas dengan kinerja Value for Money. Selain itu, penelitian yang dilakukan oleh (Setiyaningrum 2016) menjelaskan bahwa terhadap hubungan yang positif dan signifikan antara akuntabilitas dengan kinerja anggaran berkonsep Value for Money. (Intihanah \& Muthia 2016) juga melakukan penelitian mengenai pengaruh Good Government Governance dengan akuntabilitas sebagai salah satu prinsipnya terhadap kinerja pemerintah dan memperoleh hasil yang signifikan antara keduanya. Penelitian yang dilakukan oleh (Prayoga 2017) mengungkapkan bahwa terdapat pengaruh yang signfikan antara transparansi sebagai salah satu indikator Good Government Governance terhadap kinerja pemerintah daerah. Maka berdasarkan penjelasan di atas, dapat diturunkan hipotesis sebagai berikut:

$\mathrm{H}_{2}$ : Akuntabilitas berpengaruh positif terhadap Ekonomis.

Aturan hukum merupakan sebuah ldanasan yang digunakan oleh setiap kelompok orang dalam melaksanaan kegiatan. Apabila aturan hukum dapat dilaksanakan dengan baik, maka akan tercipta sebuah kinerja yang sesuai dengan prosedur yang telah ditetapkan, salah satu contohnya adalah dapat meningkatkan ekonomisasi angggaran. Semakin baik aturan, maka akan semakin baik pemerintah dalam melakukan alokasi anggaran. Hal ini didukung oleh penelitian sebelumnya yang dilakukan oleh (Fajarningtyas, Muslimin, \& Kahar 2016) (Intihanah \& Muthia 2016) (Pratolo, Jatmiko, \& Ardhi 2015) (Syurgawi 2015) yang meneliti tentang pengaruh dari Good Government Governance yang salah satunya melalui aturan hukum sebagai alat ukurnya terhadap kinerja Value for Money. Hasil penelitian tersebut menunjukkan bahwa Good Government Governance melalui aturan hukum berpengaruh positif dan signifikan terhadap kinerja Value for Money. Akhmaddhian, 2016 juga menjelaskan bahwa terdapat pengaruh yang signfikan apabila aturan hukum dilaksanakan terhadap 
pertumbuhan ekonomi di Indonesia. Maka berdasarkan penejelasan di atas, dapat diturunkan hipotesis sebagai berikut:

$\mathrm{H}_{3}$ : Aturan hukum berpengaruh positif terhadap Ekonomis.

Prinsip-prinsip Good Government Governance transparansi yang dilakukan oleh pejabat publik dapat berpengaruh terhadap efisiensi. Hal ini didukung oleh penelitian sebelumnya yang dilakukan oleh (Pratolo, Jatmiko, \& Ardhi 2015) (Pratolo, Jatmiko, \& Manuhara 2015) (Intihanah \& Muthia 2016) (Claraini 2017) bahwa transparansi yang merupakan prinsip dari Good Governance dapat meningkatkan kinerja perguruan tinggi. Maka berdasarkan penejelasan diatas, dapat diturunkan hipotesis sebagai berikut:

$\mathrm{H}_{4}$ : Transparansi berpengaruh positif terhadap Efisiensi.

Akuntabilitas berkaitan dengan tanggungjawab yang dilakukan oleh pejabat publik mengenai kinerja yang telah dilakukan. Semakin baik penerapan akuntabilitas yang dilakukan oleh pejabat publik, maka artinya pemerintah dapat mengelola sumber daya dengan baik, sehingga terciptanya pengelolaan terhadap efisien yang merupakan prinsip dari Value for Money. Hal ini didukung oleh penelitian sebelumnya yang dilakukan oleh (Pratolo, Jatmiko, \& Manuhara 2015) bahwa akuntabilitas yang merupakan prinsip dari Good Governance dapat meningkatkan kinerja perguruan tinggi. Intihanah \& Muthia 2016 juga melakukan penelitian mengenai pengaruh Good Government Governance dengan akuntabilitas sebagai salah satu prinsipnya terhadap kinerja pemerintah dan memperoleh hasik yang signifikan antara keduanya. Penelitian yang dilakukan oleh (Prayoga 2017) mengungkapkan bahwa terdapat pengaruh yang signfikan antara akuntabilitas sebagai salah satu indikator Good Government Governance terhadap kinerja pemerintah daerah. Hal tersebut terdukung oleh penelitian sebelumnya yang dilakukan oleh (Ferry, Eckrersley, \& Zakaria 2015) bahwa akuntabilitas memiliki implikasi siginifikan terhadap layanan publik. Maka berdasarkan penjelasan di atas, dapat diturunkan hipotesis sebagai berikut:

$\mathrm{H}_{5}$ : Akuntabilitas berpengaruh positif terhadap Efisiensi.

Aturan hukum merupakan prinsip dari Good Governance yang harus diterapkan saat ini. Penegakan hukum yang baik akan berdampak pada kinerja Value for Money pemerintah, yang salah satu alat ukurnya adalah efisiensi. Aturan-aturan yang diberlakukan secara tegas, dapat mempengaruhi kinerja yang dilakukan oleh pejabat publik, sehingga megurangi penyelewengan yang dilakukan oleh pejabat publik. Hal tersebut didukung dengan penelitian yang dilakukan oleh (Pratolo, Jatmiko, \& Ardhi 2015) dan (Syurgawi 2015) bahwa aturan hukum yang merupakan prinsip Good Governane Government berpengaruh terhadap kinerja pemerintah daerah. Akhmaddhian (2016) juga menjelaskan bahwa terdapat pengaruh yang signfikan apabila aturan hukum dilaksanakan terhadap pertumbuhan ekonomi di Indonesia. Fajarningtyas, Muslimin, \& Kahar (2016) menjelaskan bahwa Good Government Governance melalui aturan hukum berpengaruh positif dan signifikan terhadap kinerja Value for Money. Maka berdasarkan penjelasan di atas, dapat diturunkan hipotesis sebagai berikut:

$\mathrm{H}_{6}$ : Aturan hukum berpengaruh positif terhadap Efisiensi.

Unsur transparansi di dalam lingkup pemerintahan merupakan hal yang sangat penting yang dapat menciptakan hubungan harmonis serta rasa kepercayaan antara pemerintah dengan masyarakat. Dengan adanya 
transparansi, masyarakat dan pihak luar lain dapat mengetahui kinerja yang dilakukan oleh pejabat publik sudah sesuai dengan dengan target yang telah ditetapkan. Hal tersebut didukung dengan penelitian yang dilakukan oleh Pratolo, Jatmiko, \& Ardhi (2015) bahwa trasparansi mempunyai dampak dan berpengaruh terhadap kinerja pemerintah daerah. Akhmaddhian (2016) menjelaskan bahwa transparansi berpengaruh positif dan signifikan terhadap efektivitas pelaksanaan anggaran. Fajarningtyas, Muslimin, \& Kahar (2016) menjelaskan bahwa terdapat pengaruh yang positif dan signifikan antara Good Government Governance melalui prinsip transparansi terhadap kinerja Value for Money. Setiyaningrum (2016) menjelaskan bahwa terhadap hubungan yang positif dan signifikan antara transparansi dengan kinerja anggaran berkonsep Value for Money. Intihanah \& Muthia (2016) juga melakukan penelitian mengenai pengaruh Good Government Governance dengan transparansi sebagai salah satu prinsipnya terhadap kinerja pemerintah dan memperoleh hasil yang signifikan antara keduanya. Maka berdasarkan penjelasan di atas, dapat diturunkan hipotesis sebagai berikut:

$\mathrm{H}_{7}$ : Transparansi berpengaruh positif terhadap Efektifitas.

Akuntabilitas berkaitan dengan tanggungjawab yang dilakukan oleh pejabat publik mengenai kienerja yang telah dilakukan. Keberhasilan suatu organisasi pemerintah dapat diukur dengan perspektif pengelolaan keuangan daerah yang tepat dapat memberikan kepastian mengenai keberhasilan atau ketepatan suatu kegiatan sehingga pemerintah terus melakukan berbagai upaya untuk meningkatkan transparansi dan akuntabilitas pengelolaan keuangan daerahnya (Ruspina 2013). Semakin baik penerapan akuntabilitas yang dilakukan oleh pejabat publik, maka pertanggungjawaban yang dilakukan akan semakin tinggi sehingga meningkatkan efektivitas kinerja yang merupakan salah satu prinsip dari Value for Money. Hal tersebut didukung oleh penelitian sebelumnya yang dilakukan oleh Akhmaddhian (2016) bahwa akuntabilitas berpengaruh positif dan signifikan terhadap efektivitas pelaksanaan anggaran. Intihanah \& Muthia (2016) juga melakukan penelitian mengenai pengaruh Good Government Governance dengan akuntabilitas sebagai salah satu prinsipnya terhadap kinerja pemerintah dan memperoleh hasil yang signifikan antara keduanya. Hal tersebut terdukung oleh penelitian sebelumnya yang dilakukan oleh Ferry, Eckrersley, \& Zakaria (2015) bahwa akuntabilitas memiliki implikasi siginifikan terhadap layanan publik. Penelitian lain yang dilakukan oleh Tambunan (2010) juga mengungkapkan bahwa terdapat pengaruh yang signfikan antara akuntabilitas terhadap efektivitas kinerja pegawai. Penelitian yang dilakukan oleh Prayoga (2017) mengungkapkan bahwa terdapat pengaruh yang signfikan antara akuntabilitas sebagai salah satu indikator Good Government Governance terhadap kinerja pemerintah daerah. Maka berdasarkan penjelasan diatas, dapat diturunkan hipotesis sebagai berikut:

$\mathrm{H}_{8}$ : Akuntabilitas berpengaruh positif terhadap Efektivitas.

Agar terciptanya pencapaian kinerja sesuai dengan ukuran dan indikator yang telah ditetapkan, maka aturan hukum yang tegas perlu dilakukan. Pejabat akan merasa takut jika akan melakukan tindakan yang tidak sesuai dengan indikator yang telah ditetapkan. Semakin baik penerapan hukum dalam pemerintah, maka akan meningkatkan efektivitas kinerja dari pemerintah. Hal 
tersebut didukung dengan penelitian yang dilakukan oleh Pratolo, Jatmiko, \& Ardhi (2015) bahwa penegakkan hukum berpengaruh positif terhadap efektivitas. Akhmaddhian (2016) juga menjelaskan bahwa terdapat pengaruh yang signfikan apabila aturan hukum dilaksanakan terhadap pertumbuhan ekonomi di Indonesia. Penelitian sebelumnya yang dilakukan oleh Fajarningtyas, Muslimin, \& Kahar (2016) yang meneliti tentang pengaruh dari Good Government Governance yang salah satunya melalui aturan hukum sebagai alat ukur terhadap kinerja Value for Money. Syurgawi (2015) juga mengungkapkan bahwa terdapat pengaruh yang signfikan antara aturan hukum yang merupakan prinsip Good Government Governance terhadap kinerja pemerintah. Hal tersebut juga didukung oleh penelitian sebelumnya yang dilakukan oleh Intihanah \& Muthia (2016) yang meneliti tentang pengaruh Good Government Governance dengan menggunakan salah satunya prinsip aturan hukum terhadap kinerja pemerintah daerah. Hasilnya adalah terdapat hubungan yang signifikan terhadap kinerja pemerintah daerah. Maka berdasarkan penejelasan di atas, dapat diturunkan hipotesis sebagai berikut:

$\mathrm{H}_{9}$ : Penegakan hukum berpengaruh positif terhadap Efektifitas.

\section{METODE PENELITIAN}

Subyek dalam penelitian kuantitatif ini yaitu Satuan Kerja Perangkat Daerah (SKPD) Kabupaten Kebumen dari Dinas serta Badan Pemerintah Daerah Kabupen Kebumen. Data primer diperoleh melalui kuisioner yang disebar secara langsung kepada responden pada masing-masing bagian SKPD di Kabupaten Kebumen. Sampel dalam penelitian ini adalah 15 SKPD yang ada di Kabupaten Kebumen. Teknik pengambilan sampel dilakukan dengan menggunakan Probability Sampling dengan metode Purposive sampling. Adapun kriteria yang digunakan sebagai sampel yaitu: 1) para pegawai/staff di Kabupaten Kebumen yang menduduki jabatan pada tingkatan eselon 3 dan eselon 4 setingkat Kepala Bagian, Kepala Bidang, Kepala Seksi, Kepala Sub Bagian; dan 2) pegawai/staff yang sudah menjabat atau bekerja minimal selama 1 tahun. Teknik pengumpulan data dilakukan dengan menggunakan metode survey dengan pengumpulan data primer, yaitu kuesioner.

Variabel independen pada penelitian ini yaitu transparansi, akuntabilitas, dan penegakan hukum. Variabel dependen pada penelitian ini yaitu ekonomis, efisiensi, dan efektivitas. Transparansi diukur dari keterbukaan informasi publik yang disajikan pada website. Akuntabilitas merupakan bentuk pertanggungjawaban yang dilihat dari segi proses anggaran, pengelolaan anggaran, pertanggungjawaban anggaran, serta pengevaluasian anggaran. Penegakkan hukum merupakan upaya pemerintah dalam memberikan keadilan yang dilihat dari segi kepatuhan terhadap hukum, pemberian penghargaan dan hukuman, serta penindakantegas terhadap pelanggaran. Pengukuran variabel ekonomi dilihat dari segi kualitas dan kuantitas yang terdiri dari: pemilihan serta pengalokasian sumber daya, pemilihan barang/jasa dengan harga rendah namun tetap dengan kualitas yang tinggi. Efisiensi merupakan capaian dari keluaran harga maksimum untuk memperoleh keluaran yang maksimal dengan cara pengukuran yaitu melihat pengadaan sumber daya yang sesuai dengan kebutuhan, menggunakan sumber daya output secara optimal serta 
penghindaran dari pekerjaan tanpa tujuan yang tidakjelas. Pengukuran variabel efektivitas melihat kebijakan dan prosedur yang terdiri dari pengidentifikasian faktor pengambat kinerja, sistem pengendalian manajemen serta melakukan pengukuran dan pelaporan dalam setiap kegiatan.

Data dalam penelitian akan dilakukan uji analisis data. Analisis regresi linear berganda digunaan dalam penelitian ini. Uji signifikansi simultan (Uji F) digunakan untuk melihat apakah variabel independen secara bersama-sama mempunyai pengaruh yang signifikan terhadap variabel dependen. Uji signifikansi parsial (Uji t) dilakukan untuk mengetahui apakah pengaruh masing-masing variabel bebas dan variabel terikat signifikan atau tidak. Sedangkan koefisiensi determinasi digunakan untuk mengukur sejauh mana variabel independen mampu menjelaskan variabel dependen.

\section{HASIL DAN PEMBAHASAN}

Uji asumsi klasik yang dilakukan terdiri dari uji normalitas, multikolinearitas dan heteroskedastisitas. Uji normalitas dilakukan dengan uji Kolmogorov Smirnov. Ditemukan nilai sig. 0,257 pada persamaan regresi pertama. Nilai signifikansi tersebut lebih besar dari alpha 0,05, sehingga dapat disimpulkan bahwa residual berdistribusi normal. Berikutnya, hasil uji multikolinearitas melalui nilai tolerance seluruh variabel independen lebih dari 0,1 dan untuk nilai VIF kurang dari 10. Dari nilai tersebut maka dapat disimpulkan bahwa tidak terjadi multikolinearitas di antara masing-masing variabel independen. Berikutnya hasil uji heteroskedastisitas menunjukkan bahwa hasil uji memiliki nilai signifikansi lebih besar dari alpha 0,05 untuk seluruh variabel. Sehingga, dapat disimpulkan bahwa data yang ada dalam penelitian ini tidak terjadi heteroskedastisitas. Karena telah terpenuhinya uji validitas dan realibitas instrument dan asumsi klasik, maka pengujian hipotesis dapat dilakukan pada tahap selanjutnya. Uji Signifikansi Simultan (Uji-F) digunakan dalam penelitian ini. Berikut adalah tabel 1. Terkait dengan hasil uji F.

Tabel 1. Signifikansi Simultan (Uji-F)

\begin{tabular}{lll}
\hline Model & & Sig. \\
\hline 1 & Regression Residual Total & $.000(\mathrm{a})$ \\
2 & Regression Residual Total & $.000(\mathrm{a})$ \\
3 & Regression Residual Total & .000 (a) \\
\hline
\end{tabular}

Sumber: Data Penelitian, 2018

Nilai signifikansi $F$ 0,000 < a 0,05, sehingga dapat disimpulkan bahwa variabel akuntabilitas, transparansi, dan aturan hukum secara bersama-sama atau secara simultan berpengaruh terhadap variabel ekonomis. Nilai signifikansi F $0,000<$ a 0,05 , sehingga dapat disimpulkan bahwa variabel akuntabilitas, transparansi, dan aturan hukum secara bersama-sama atau secara simultan berpengaruh terhadap variabel efisiensi. Nilai signifikansi $F$ 0,000 < a 0,05, sehingga dapat disimpulkan bahwa variabel akuntabilitas, transparansi, dan aturan hukum secara bersama-sama atau secara simultan berpengaruh terhadap variabel efektivitas. Berikut adalah tabel hasil uji t. 
Tabel 2. Uji-t

\begin{tabular}{lllllll}
\hline & \multicolumn{2}{c}{ Variabel Ekonomis } & \multicolumn{2}{c}{ Variabel Efisiensi } & \multicolumn{2}{c}{ Variabel Efektivitas } \\
\cline { 2 - 7 } & $\mathrm{B}$ & Sig, & $\mathrm{B}$ & Sig, & $\mathrm{B}$ & Sig, \\
\hline 1 (constant) & 6,766 & 0,000 & 10,122 & 0,003 & 11,987 & 0,000 \\
Akuntabilitas & 0,095 & 0,234 & 0,135 & 0,219 & 0,170 & 0,067 \\
Transparansi & 0,214 & 0,007 & 0,267 & 0,014 & 0,240 & 0,008 \\
Aturan & 0,499 & 0,000 & 0,341 & 0,001 & 0,278 & 0,001 \\
Hukum & & & & & & \\
\hline
\end{tabular}

Sumber : Data Penelitian, 2018

Nilai signifikansi pada variabel transparansi yaitu $0,007<a 0,05$ dan nilai kefisien regresi sebesar 0,214. Dengan demikian dapat disimpulkan jika variabel transparansi berpengaruh positif terhadap penerapan ekonomis kinerja SKPD. Hal tersebut menujukkan bahwa hipotesis pertama $\left(\mathrm{H}_{1}\right)$ diterima. Nilai signifikansi pada variabel akuntabilitas yaitu 0,234 > a 0,05 dan nilai koefisien regresi sebesar 0,095. Dengan demikian dapat disimpulkan jika variabel akuntabilitas tidak berpengaruh terhadap penerapan ekonomis kinerja SKPD. Hal tersebut menujukkan bahwa hipotesis kedua $\left(\mathrm{H}_{2}\right)$ ditolak. Nilai signifikansi pada variabel aturan hukum yaitu $0,000<$ a 0,05 dan nilai koefisien regresi sebesar 0,499. Dengan demikian dapat disimpulkan jika variabel aturan hukum berpengaruh positif terhadap penerapan ekonomis kinerja SKPD. Hal tersebut menujukkan bahwa hipotesis ketiga $\left(\mathrm{H}_{3}\right)$ diterima.

Nilai signifikansi pada variabel transparansi yaitu $0,014<$ a 0,05 dan nilai koefisien regresi sebesar 0,267 . Dengan demikian dapat disimpulkan jika variabel transparansi berpengaruh positif terhadap penerapan efisiensi kinerja SKPD. Hal tersebut menujukkan bahwa hipotesis keempat $\left(\mathrm{H}_{4}\right)$ diterima. Nilai signifikansi pada variabel akuntabilitas yaitu $0,219>$ a 0,05 dan nilai koefisien regresi sebesar 0,135. Dengan demikian dapat disimpulkan jika variabel akuntabilitas tidak berpengaruh terhadap penerapan efisiensi kinerja SKPD. Hal tersebut menujukkan bahwa hipotesis kelima $\left(\mathrm{H}_{5}\right)$ ditolak. Nilai signifikansi pada variabel aturan hukum yaitu 0,001 < a 0,05 dan nilai koefisien regresi sebesar 0,341. Dengan demikian dapat disimpulkan jika variabel aturan hukum berpengaruh positif terhadap penerapan efisiensi kinerja SKPD. Hal tersebut menujukkan bahwa hipotesis keenam $\left(\mathrm{H}_{6}\right)$ diterima.

Nilai signifikansi pada variabel transparansi yaitu $0,008<a \quad 0,05$ dan nilai koefisien regresi sebesar 0,240 . Dengan demikian dapat disimpulkan jika variabel transparansi berpengaruh positif terhadap penerapan efektivitas kinerja SKPD. Hal tersebut menujukkan bahwa hipotesis ketuju $\left(\mathrm{H}_{7}\right)$ diterima. Nilai signifikansi pada variabel akuntabilitas yaitu 0,067 > a 0,05 dan nilai koefisien regresi sebesar 0,170. Dengan demikian dapat disimpulkan jika variabel akuntabilitas tidak berpengaruh terhadap penerapan efektivitas kinerja SKPD. Hal tersebut menujukkan bahwa hipotesis kedelapan $\left(\mathrm{H}_{8}\right)$ ditolak. Nilai signifikansi pada variabel aturan hukum yaitu 0,001 < a 0,05 dan nilai koefisien regresi sebesar 0,278. Dengan demikian dapat disimpulkan jika variabel aturan hukum berpengaruh positif terhadap penerapan efektivitas kinerja SKPD. Hal tersebut menujukkan bahwa hipotesis kesembilan $\left(\mathrm{H}_{9}\right)$ diterima. 
Tabel 3. Hasil Uji Adjusted R2 Ekonomis, Efisiensi, dan Efektivitas

\begin{tabular}{ll}
\hline Model & Adjusted R Square \\
\hline 1 & .663 \\
2 & .452 \\
3 & .497
\end{tabular}

Sumber: Data Penelitian, 2018

Nilai Adjsted $R^{2}$ sebesar 0,663. Hal tersebut menujukkan jika 66,3\% variasi dari variabel ekomonis daapat dijelaskan oleh variabel transparansi, akuntabilitas, dan aturan hukum. Sisanya 33,7\% dijelaskan oleh variabel lainnya yang tidak terdapat didalam penelitian ini. Nilai Adjsted $R^{2}$ sebesar 0,452 . Hal tersebut menujukkan jika 45,2\% variasi dari variabel efisiensi dapat dijelaskan oleh variabel transparansi, akuntabilitas, dan aturan hukum. Sisanya 54,8\% dijelaskan oleh variabel lainnya yang tidak terdapat didalam penelitian ini. Nilai Adjsted $R^{2}$ sebesar 0,497. Hal tersebut menujukkan jika 49,7\% variasi dari variabel efektivitas daapat dijelaskan oleh variabel transparansi, akuntabilitas, dan aturan hukum. Sisanya 50,3\% dijelaskan oleh variabel lainnya yang tidak terdapat didalam penelitian ini.

Hasil pengujian hipotesis untuk variabel transparansi didapatkan nilai signifikansi pada variabel transparansi yaitu 0,007 < a 0,05 dan nilai koefisien regresi sebesar 0,214, hal tersebut menunjukkan bahwa transparansi berpengaruh positif terhadap ekonomis SKPD di Kabupaten Kebumen. Semakin baik penerapan transparansi, maka semakin meningkat pula prinsip ekonomis yang merupakan salah satu prinsip dari Value for Money Method pada Satuan Kerja Perangkat Daerah di Kabupaten Kebumen. Transparansi pada SKPD Kabupaten Kebumen ditdanai dengan adanya penggunaan website resmi pemerintah. Website resmi ini digunakan sebagai media publik untuk mengakses informasi pemerintahan seputar anggaran, laporan pertanggungjawaban, penampungan usulan, dan pengumuman anggaran.

Hasil penelitian ini didukung dengan hasil penelitian yang dilakukan oleh Pratolo, Jatmiko, \& Ardhi (2015), Ljungholm (2015), Setiyaningrum (2016), Fajarningtyas, Muslimin, \& Kahar (2016), Intihanah \& Muthia (2016) bahwa penerapan prinsip transparansi yang merupakan prinsip dari Good Government Governance berpengaruh positif dan signifikan terhadap kinerja anggaran berkonsep Value for Money yang didalamnya terdapat prinsip ekonomis.

Hasil pengujian hipotesis untuk variabel transparansi didapatkan nilai signifikansi pada pada variabel akuntabilitas yaitu 0,234 > a 0,05 dan nilai koefisien regresi sebesar 0,095. Artinya bahwa penerapan akuntabilitas tidak berpengaruh terhadap ekonomis yang merupakan prinsip dari kinerja Value for Money pada SKPD Kabupaten Kebumen. Hal tersebut terjadi karena tahapan pengelolaan anggaran melibatkan unsur masyarakat belum dilakukan dengan baik, akuntabilitas kejujuran digunkan badan dalam melakukan penyusunan anggaran belum dilakukan dengan cukup baik, anggaran disajikan secara tepat, terbuka, dan tepat kepada seluruh masyarakat belum terlalu dilakukan dengan baik, kepentingan stakeholder menjadi perhatian utama dalam pengelolaan anggaran belum terlalu dilakukan dengan baik, penggunaan dana anggaran didasarkan atas hukum dan peraturan yang berlaku belum dilakukan dengan 
baik, penerapan anggaran merupakan dokumen yang tidak bersifat rahasia juga belum diterapkan dengan cukup baik, indikator hasil kinerja yang dicapai akan digunakan untuk mengevaluasi anggaran sudah cukup baik, dalam mengevaluasi anggaran dilakukan dengan membdaningkan antara target realisasi dengan sesungguhnya sudah cukup baik, dan pelaksanaan serta pertanggungjawaban anggaran harus diawasi secara terus menerus belum cukup baik. Hasil penelitian ini sejalan dengan hasil penelitian yang dilakukan oleh Lestiawan \& Jatmiko (2015) bahwa penerapan prinsip akuntabilitas yang merupakan prinsip dari Good Government Governance tidak berpengaruh terhadap kinerja anggaran berkonsep Value for Money yang didalamnya terdapat prinsip ekonomis.

Berdasarkan hasil pengujian hipotesis untuk variabel aturan hukum, didapatkan nilai signifikansi pada variabel aturan hukum yaitu 0,000 < a 0,05 dan nilai koefisien regresi sebesar 0,499. Hal tersebut menunjukkan bahwa aturan hukum berpengaruh secara positif dan signfikan terhadap ekonomis pada Satuan Kerja Perangkat Daerah di Kabupaten Kebumen. Artinya semakin baik dan tegas penerapan aturan hukum maka semakin meningkat pula kinerja pemerintah daerah sesuai dengan prinsip ekonomis yang merupakan salah satu prinsip Value for Money. Hal tersebut terjadi karena adanya fungsi dalam organisasi yang menelaah tingkat kepatuhan pemerintah terhadap peraturan sudah dilakukan dengan baik, adanya jaminan pemberian teguran kepada setiap SKPD apabila terjadi kesalahan dalam melaksanakan tugasnya sudah cukup baik, melakukan penindaktegasan kepada SKPD berupa pemberian sanksi bagi yang melakukan pelenggaran sudah dilakukan dengan cukup baik, adanya upayan untuk melakukan penyalahgunaan sudah dapat dicegah dengan cukup baik, penyamarataan pemberian sanksi belum terlalu baik karena para pegawai mengharapkan adanya perbedaan pemberian sanksi pada masing-masing tingkatan jabatan, adanya fungsi dalam organisasi yang memantau kepatuhan pemerintah terhadap peraturan yang berlaku sudah baik, adanya penindaktegasan kepada pegawai yang melakukan pelanggaran disiplin sudah baik, dan adanya hak stakeholders untuk dilindungi sesuai dengan hukum sudah baik. Berdasarkan informasi diatas mengenai hasil dari jawaban responden pada kuesioner tentang prinsip aturan hukum, maka secara garis besar dapat dikatakan bahwa penerapan prinsip aturan hukum pada SKPD di Kabupaten Kebumen sudah dilakukan dengan baik dan tegas, sehingga penerapan aturan hukum tersebut berpengaruh secara signifikan dan positif terhadap peningkatan ekonomis SKPD di Kabupaten Kebumen. Hal tersebut sejalan dengan penelitian yang telah dilakukan oleh (Fajarningtyas, Muslimin, \& Kahar., 2016), (Akhmaddhian 2016), (Pratolo, Jatmiko, \& Ardhi, 2015), (Intihanah \& Muthia, 2016) yang menyatakan bahwa penerapan prinsip aturan hukum yang merupakan prinsip Good Government Governance terhadap kinerja pemerintah daerah dan kinerja pemerintah daerah berkonsep Value for Money.

Hasil pengujian hipotesis dari variabel transparansi didapatkan nilai signifikansi pada variabel transparansi yaitu 0,014 < a 0,05 dan nilai koefisien regresi sebesar 0,267. Artinya bahwa semakin baik penerapan prinsip transparansi berpengaruh terhadap efisiensi yang merupakan prinsip dari Value for Money Moethod pada Satuan Kerja Perangkat Daerah Kabupaten Kebumen. 
Hal tersebut terjadi karena pemberian informasi kepada publik sudah baik, penggunaan website resmi pemerintah sudah baik, Undang-undang Nomor 14 tahun 2008 tentang keterbukaan informasi publik sudah dilakukan dengan baik, kemudahan dalam mengakses dokumen publik tentang anggaran sudah cukup baik, laporan pertanggungjawaban tahunan sudah diterapkan dengan cukup baik pula, transparansi anggaran dapat menampung usulan juga sudah diterapkan dengan baik, pengumuman anggaran bisa diperoleh dalam setiap waktu sudah dilakukan dengan cukup baik namun masih perlu adanya peningkatan, pengumuman anggaran kepada masyarakat sudah baik, dan dokumen publik tentang anggaran mudah untuk diakses dan bersifat terbuka sudah baik. Berdasarkan informasi diatas mengenai hasil dari jawaban responden pada kuesioner tentang prinsip transparansi, maka secara garis besar dapat dikatakan bahwa penerapan prinsip transparansi pada SKPD di Kabupaten Kebumen sudah dilakukan dengan baik dan tegas, sehingga penerapan transparansi tersebut berpengaruh secara signifikan dan positif terhadap peningkatan efisiensi SKPD di Kabupaten Kebumen. Hal tersebut sejalan dengan beberapa penelitian yang telah dilakukan oleh Pratolo, Jatmiko, \& Manuhara (2015), Ljungholm (2015), Pratolo, Jatmiko, \& Ardhi (2015), Claraini (2017) yang menyatakan bahwa terdapat pengaruh yang signfikan terhadap penerapan Good Government Governance yang salah satunya terdapat prinsip transparansi terhadap kinerja daripada pemerintah daerah.

Hasil pengujian hipotesis dari variabel akuntabilitas didapatkan nilai signifikansi pada variabel akuntabilitas yaitu $0,219>$ a 0,05 dan nilai koefisien regresi sebesar 0,135 . Hal tersebut menunjukkan bahwa penerapan prinsip akuntabilitas tidak berpengaruh terhadap efisiensi pada Satuan Kerja Perangkat Daerah Kabupaten Kebumen. Artinya penerapan prinsip akuntabilitas dalam lingkup Kabupaten Kebumen tidak mempunyai pengaruh terhadap tingkat efisiensi dari pemerintah daerah. Hal tersebut terjadi karena tahapan pengelolaan anggaran melibatkan unsur masyarakat belum dilakukan dengan baik, akuntabilitas kejujuran digunakan badan dalam melakukan penyusunan angaran belum dilakukan dengan cukup baik, anggaran disajikan secara tepat, terbuka, dan tepat kepada seluruh masyarakat belum terlalu dilakukan dengan baik, kepentingan stakeholder menjadi perhatian utama dalam pengelolaan anggaran belum terlalu dilakukan dengan baik, penggunaan dana anggaran didasarkan atas hukum dan peraturan yang berlaku belum dilakukan dengan baik, penerapan anggaran merupakan dokumen yang tidak bersifat rahasia juga belum diterapkan dengan cukup baik, indikator hasil kinerja yang dicapai akan digunakan untuk mengevaluasi anggaran sudah cukup baik, dalam mengevaluasi anggaran dilakukan dengan membdaningkan antara target realisasi dengan sesungguhnya sudah cukup baik, dan pelaksanaan serta pertanggungjawaban anggaran harus diawasi secara terus menerus belum cukup baik. Berdasarkan informasi diatas mengenai hasil dari jawaban responden yang berhubungan tentang prinsip akuntabilitas, maka secara garis besar dapat dikatakan bahwa penerapan prinsip akuntabilitas pada SKPD di Kabupaten Kebumen belum dilakukan dengan cukup baik, sehingga penerapan akuntabilitas tersebut tidak berpengaruh secara signifikan terhadap efisiensi pada SKPD di Kabupaten Kebumen. Hasil penelitian ini sejalan dengan hasil 
penelitian yang dilakukan oleh Lestiawan \& Jatmiko (2015) bahwa penerapan prinsip akuntabilitas yang merupakan prinsip dari Good Government Governance tidak berpengaruh terhadap kinerja anggaran berkonsep Value for Money yang didalamnya terdapat prinsip ekonomis.

Hasil pengujian hipotesis untuk variabel aturan hukum didapatkan nilai signifikansi pada variabel aturan hukum yaitu $0,001<a$ 0,05 dan nilai koefisien regresi sebesar 0,341. Hal tersebut menujukkan jika penerapan aturan hukum berpengaruh terhadap efisiensi dari Satuan Kerja Perangkat Daerah Kabupaten Kebumen. Artinya semakin tegas dan baik pemerintah menerapkan aturan hukum, maka semakin meningkat pula efisiensi dari pemerintah daerah Kabupaten Kebumen. Hal tersebut terjadi karena adanya fungsi dalam organisasi yang menelaah tingkat kepatuhan pemerintah terhadap peraturan sudah dilakukan dengan baik, adanya jaminan pemberian terguran kepada setiap SKPD apabila terjadi kesalahan dalam melaksanakan tugasnya sudah cukup baik, melakukan penindaktegasan kepada SKPD berupa pemberian sanksi bagi yang melakukan pelenggaran sudah dilakukan dengan cukup baik, adanya upayan untuk melakukan penyalahgunaan sudah dapat dicegah dengan cukup baik, penyamarataan pemberian sanksi belum terlalu baik karena para pegawai mengharapkan adanya perbedaan pemberian sanksi pada masing-masing tingkatan jabatan, adanya fungsi dalam organisasi yang memantau kepatuhan pemerintah terhadap peraturan yang berlaku sudah baik, adanya penindaktegasan kepada pegawai yang melakukan pelanggaran disiplin sudah baik, dan adanya hak stakeholders untuk dilindungi sesuai dengan hukum sudah baik. Berdasarkan informasi diatas mengenai hasil dari jawaban responden yang berhubungan tentang prinsip aturan hukum, maka secara garis besar dapat dikatakan bahwa penerapan prinsip aturan hukum pada SKPD di Kabupaten Kebumen sudah dilakukan dengan baik dan tegas, sehingga penerapan aturan hukum tersebut berpengaruh secara signifikan dan positif terhadap peningkatan efisiensi SKPD di Kabupaten Kebumen. Hasil penelitian ini sejalan dengan penelitian yang dilakukan oleh Pratolo, Jatmiko, \& Ardhi (2015), Intihanah \& Muthia (2016), Akhmaddhian (2016), Fajarningtyas, Muslimin, \& Kahar (2016), Syurgawi (2015) yang mengungkapkan bahwa terdapat pengaruh yang signfikan penerapan aturan hukum yang merupakan prinsip Good Government Governance terhadap kinerja berkonsep Value for Money maupun kinerja yang tidak berkonsep Value for Money daripada pemerintah daerah.

Hasil pengujian hipotesis untuk variabel transparansi didapatkan nilai signifikansi pada variabel transparansi yaitu 0,008 < a 0,05 dan nilai koefisien regresi sebesar 0,240 . Hal tersebut menunjukkan bahwa terdapat pengaruh yang signifikan dan positif antara penerapan transparansi terhadap efektivitas Satuan Kerja Perangkat Daerah di Kabupaten Kebumen. Artinya semakin baik penerapan transparansi dilakukan, maka akan semakin meningkat pula efektivitas dari Satuan Kerja Perangkat Daerah di Kabupaten Kebumen. Hal tersebut terjadi karena pemberian informasi kepada publik sudah baik, penggunaan website resmi pemerintah sudah baik, Undang-undang Nomor 14 tahun 2008 tentang keterbukaan informasi publik sudah dilakukan dengan baik, kemudahan dalam mengakses dokumen publik tentang anggaran sudah cukup 
baik, laporan pertanggungjawaban tahunan sudah diterapkan dengan cukup baik pula, transparansi anggaran dapat menampung usulan juga sudah diterapkan dengan baik, pengumuman anggaran bisa diperoleh dalam setiap waktu sudah dilakukan dengan cukup baik namun masih perlu adanya peningkatan, pengumuman anggaran kepada masyarakat sudah baik, dan dokumen publik tentang anggaran mudah untuk diakses dan bersifat terbuka sudah baik.

Mendasari informasi diatas mengenai hasil dari jawaban responden yang berhubungan tentang prinsip transparansi, maka secara garis besar dapat dikatakan bahwa penerapan prinsip transparansi pada SKPD di Kabupaten Kebumen sudah dilakukan dengan baik dan tegas, sehingga penerapan transparansi tersebut memiliki pengaruh secara signifikan dan positif terhadap peningkatan efektivitas pada SKPD di Kabupaten Kebumen. Hasil pengujian tersebut sejalan dengan penelitian sebelumnya yang dilakukan oleh (Akhmaddhian, 2016) yang menyatakan bahwa transparansi berpengaruh terhadap efektivitas pelaksanaan anggaran pada SKPD Kabupaten Batang Hari. Selain itu Pratolo, Jatmiko, \& Ardhi (2015), Setiyaningrum (2016), Intihanah \& Muthia (2016) yang menyatakan bahwa terdapat hubungan yang signfikan antara transparansi yang merupakan salah satu prinsip dari Good Government Governance terhadap kinerja baik yang berkonsep Value for Money yang didalamnya terdapat prinsip efektivitas maupun yang tidak, sehingga semakin baik penerapan transparansi maka semakin meningkat pula efektivitas.

Hasil pengujian hipotesis untuk variabel akuntabilitas terhadap efektivitas didapatkan nilai signifikansi pada variabel akuntabilitas yaitu 0,067 > a 0,05 dan nilai koefisien regresi sebesar 0,170. Dengan demikian dapat disimpulkan jika variabel akuntabilitas tidak berpengaruh terhadap penerapan efektivitas dari Satuan Kerja Perangkat Daerah Kabupaten Kebumen. Artinya penerapan akuntabilitas pada lingkup pemerintah Kabupaten Kebumen tidak berpengaruh terhadap efektivitas dari Satuan Kerja Perangkat Daerah di Kabupaten Kebumen. Hal tersebut terjadi karena tahapan pengelolaan anggaran melibatkan unsur masyarakat belum dilakukan dengan baik, akuntabilitas kejujuran digunkan badan dalam melakukan penyusunan angaran belum dilakukan dengan cukup baik, anggaran disajikan secara tepat, terbuka, dan tepat kepada seluruh masyarakat belum terlalu dilakukan dengan baik, kepentingan stakeholder menjadi perhatian utama dalam pengelolaan anggaran belum terlalu dilakukan dengan baik, penggunaan dana anggaran didasarkan atas hukum dan peraturan yang berlaku belum dilakukan dengan baik, penerapan anggaran merupakan dokumen yang tidak bersifat rahasia juga belum diterapkan dengan cukup baik, indikator hasil kinerja yang dicapai akan digunakan untuk mengevaluasi anggaran sudah cukup baik, dalam mengevaluasi anggaran dilakukan dengan membdaningkan antara target realisasi dengan sesungguhnya sudah cukup baik, dan pelaksanaan serta pertanggungjawaban anggaran harus diawasi secara terus menerus belum cukup baik. Berdasarkan informasi diatas mengenai hasil dari jawaban responden yang berhubungan tentang prinsip akuntabilitas, maka secara garis besar dapat dikatakan bahwa penerapan prinsip akuntabilitas pada SKPD di Kabupaten Kebumen belum dilakukan dengan cukup baik, sehingga penerapan 
akuntabilitas tersebut tidak berpengaruh secara signifikan terhadap peningkatan efektivitas pada SKPD di Kabupaten Kebumen. Dan penelitian yang dilakukan oleh Lestiawan \& Jatmiko (2015) bahwa penerapan prinsip akuntabilitas yang merupakan prinsip dari Good Government Governance tidak berpengaruh terhadap kinerja anggaran berkonsep Value for Money yang didalamnya terdapat prinsip ekonomis. Namun, hasil pengujian ini bertentangan dengan penelitian yang dilakukan oleh Tambunan (2010), Ferry, Eckrersley, \& Zakaria (2015), Prayoga (2017) yang menyatakan bahwa penerapan akuntabilitas berpengaruh terhadap kinerja pemerintah daerah.

Hasil pengujian hipotesis untuk variabel aturan hukum terhadap efektivitas didapatkan nilai signifikansi pada variabel aturan hukum yaitu 0,001 $<$ a 0,05 dan nilai koefisien regresi sebesar 0,278. Artinya semakin baik dan tegas penerapan aturan hukum maka semakin meningkat pula efektivitas dari Satuan Kerja Perangkat Daerah Kabupaten Kebumen. Hal tersebut terjadi karena adanya fungsi dalam organisasi yang menelaah tingkat kepatuhan pemerintah terhadap peraturan sudah dilakukan dengan baik, adanya jaminan pemberian terguran kepada setiap SKPD apabila terjadi kesalahan dalam melaksanakan tugasnya sudah cukup baik, melakukan penindaktegasan kepada SKPD berupa pemberian sanksi bagi yang melakukan pelenggaran sudah dilakukan dengan cukup baik, adanya upayan untuk melakukan penyalahgunaan sudah dapat dicegah dengan cukup baik, penyamarataan pemberian sanksi belum terlalu baik karena para pegawai mengharapkan adanya perbedaan pemberian sanksi pada masingmasing tingkatan jabatan, adanya fungsi dalam organisasi yang memantau kepatuhan pemerintah terhadap peraturan yang berlaku sudah baik, adanya penindaktegasan kepada pegawai yang melakukan pelanggaran disiplin sudah baik, dan adanya hak stakeholders untuk dilindungi sesuai dengan hukum sudah baik. Berdasarkan informasi diatas mengenai hasil dari jawaban responden yang berhubungan tentang prinsip aturan hukum, maka secara garis besar dapat dikatakan bahwa penerapan prinsip aturan hukum pada SKPD di Kabupaten Kebumen sudah dilakukan dengan baik dan tegas, sehingga penerapan aturan hukum tersebut berpengaruh secara signifikan dan positif terhadap peningkatan efektivitas pada SKPD di Kabupaten Kebumen. Hasil pengujian tersebut sejalan dengan penelitian sebelumnya yang telah dilakukan oleh Syurgawi (2015) dan Akhmaddhian (2016) yang menyatakan bahwa penerapan aturan hukum berpengaruh signfikan terhadap kinerja pemerintah daerah. Selain itu, penelitian yang dilakukan oleh Fajarningtyas, Muslimin, dan Kahar (2016) yang menyatakan bahwa terdapat pengaruh yang signfikan penerapan Good Government Governanve yang salah satunya adalah aturan hukum terhadap kinerja berkonsep Value for Money yang didalamnya terdapat prinsip efektivitas.

\section{SIMPULAN}

Berdasarkan hasil pengujian, pengolahan, serta analisis data yang telah dilakukan, maka dapat diperoleh kesimpulan bahwa transparansi, akuntabilitas dan aturan hukum berdampak positif dan signifikan terhadap ekonomis. Hasil berikutnya menunjukkan bahwa transparansi dan aturan hukum berdampak positif dan signifikan terhadap efisiensi namun akuntabilitas tidak memberikan 
dampak signifikan terhadap efisiensi. Hasil terakhir menunjukkan bahwa transparansi dan aturan hukum memberikan dampak positif dan signifikan terhadap efektivitas namun akuntabilitas tidak memberikan dampak signifikan terhadap efektivitas. Dari hasil penelitian ini diharapkan bahwa pemerintah Kabupaten Kebumen dapat meningkatkan pemahaman atas prinsip Good Corporate Governance kepada satuan kerja pemerindah daerah.

Saran yang dapat diberkan bagi Pemerintah Daerah dalan rangka meningkatkan hasil kinerja yaitu perlu adanya peningkatan terhadpa mutu pegawai, seperti memberikan pemahaman terhadap setiap pekerjaan. Selain itu, Pemerintah Daerah diharapkan mempu memahami dan menerapkan prinsip Good Government Governance dengan baik agar terciptanya suatu kinerja sesuai dengan prinsip-prinsip kinerja berkonsep Value for Money.

Penelitian ini berfokus pada tiga prinsip Good Government Governance sehingga enam prinsip yang lain tidak dibahas. Disatu sisi penelitian ini mampu menjelaskan secara dalam ketiga prinsip tersebut namun tidak membahas keenam prinsip yang lain. Untuk meningkatkan kualitas hasil penelitian, diharapkan peneliti selanjutnya untuk mengikutsertakan metode wawancara.

\section{REFERENSI}

Akhmaddhian, S. 2016. "Penegakan Hukum Lingkungan Dan Pengaruhnya Terhadap Pertumbuhan Ekonomi Di Indoensia." Jurnal Unifikasi.

Claraini, C. 2017. "Pengaruh Good Governance, Sistem Pengendalian Intern Pemerintah Dan Gaya Kepemimpinan Terhadap Kinerja Pemerintah Daerah (Studi Pada Satuan Kerja Perangkat Daerah Kabupaten Rokan Hilir)." Jom FEKON.

Fajarningtyas, L., Muslimin, dan A. Kahar. 2016. “Pengaruh Anggaran Berbasis Kinerja Dan Good Governance Terhadap Kinerja Value For Money (Survei Pada Pemerintah Daerah Kota Palu)." Ejurnal Katalogis.

Ferry, L., P. Eckrersley, dan Z. Zakaria. 2015. "Accountability dan Transparancy in English Local Government: Moving from 'Matching Parts' to 'Ackward Couple.'" Financial Accountability dan Management.

Intihanah, dan Nur Afifah Muthia. 2016. "Pengaruh Partisipasi Anggaran Dan Good Governance Terhadap Kinerja Pemerintah Daerah (Studi Pada Dinas Kesehatan Kota Kendari)." Jurnal Akuntansi Dan Keuangan Fakultas Ekonomi Dan Bisnis UHO.

Lestiawan, H. Y., dan B. Jatmiko. 2015. "Key Success Factor Good Government Governance Serta Pengaruhnya Terhadap Kinerja Pemerintah Daerah." Maksimum.

Ljungholm, D. P. 2015. “The Impact of Transparancy in Enhancing Public Sector Performance." Contemporary Readings in Law dan Social Justice.

Pratolo, S., dan B. Jatmiko. 2017. Akuntansi Manajemen Pemerintah Daerah. Yogyakarta: LP3M UMY.

Pratolo, S., B. Jatmiko, dan K. F. Ardhi. 2015. “Good Governance Governement dan Regional Governement Performance of Depok City, Indonesia (Survey to All Local Government Institution at Depok City, West Java Province)." Proceeding ICAF UMY. 
Pratolo, S., B. Jatmiko, dan W. Manuhara. 2015. “Good University Governance Dan Kinerja PT: Model Pemetaan Dan Perencangan Kinerja PT Melalui Kualitas \& Kompetensi Lulusan, Pelayanan Serta Daya Saing Menuju Kualitas Lulusan Dan World Class University." Jurnal Akuntansi Dan Manajemen.

Prayoga, M. A. 2017. “Pengaruh Good Governance, Budaya Organisasi, Gaya Kepemimpinan, Komitmen Organisasi, Dan Pengendalian Intern Terhadap Kinerja Pemerintah Daerah (Studi Empiris Pada SKPD Kabupaten Pelalawan)." JOMFEKON.

Rahardjo, S. 1983. Masalah Penegakan Hukum. Bdanung: Sinar Baru.

Ramakrishnan, Ramachdanran. 2013. "Delivery of Public Services - The Way Forward." https://doi.org/10.13140/2.1.3753.1846.

Ruspina. 2013. "Pengaruh Kinerja Aparatur Pemerintah Daerah, Pengelolaan Keuangan Daerah, Dan Sistem Pengendalian Internal Pemerintah (SPIP) Terhadap Penerapan Good Governance (Studi Empiris Pada Pemerintah Kota Padang)." Jurnal Universitas Negeri Padang.

Setiyaningrum, I. 2016. "Pengaruh Akuntabilitas, Transparansi, Dan Pengawasan Terhadap Kinerja Anggaran Dengan Konsep Value For Money Pada Badan Usaha Milik Daerah (BUMD) Di Yogyakarta." Eprints UNY.

Syurgawi, I. 2015. "Pengaruh Karakteristik Tujuan Anggaran, Good Governance, Dan Pengawasan Apip Terhadap Kinerja Aparat Pemerintah Daerah Kabupaten Bengkalis." Jom FEKON.

Tambunan, R. L. 2010. “Pengaruh Penerapan Prinsip-Prinsip Good Governance Terhadap Efektivitas Kerja Pegawai." Repositori UNSU.

Wuldanari, dan N Endah. 2011. "Pengaruh Partisipasi Penyusunan Anggaran Pada Kinerja Aparat Pemerintah Daerah: Kepuasan Kerja Dan Komitmen Organisasi Sebagai Variabel Pemoderasi." Thesis Undergraduate Undip. 